\title{
On Analogies: Rethinking the Pacific in a Global Context
}

Teresia K Teaiwa

\begin{abstract}
This paper began its life as a keynote address at the July 2002 meeting of the European Society of Oceanists in Vienna, Austria.
\end{abstract}

Let us imagine a small but significant number of European-that is, Europe-based-scholars earnestly at work on Pacific topics in scattered, isolated locations on that turbulent continent. There is a certain exoticness to that image, and a pathos with which I, at least, can identify, having myself spent many years studying the Pacific away from the Pacific. In a funny way, the very existence of a "European Society for Oceanists" mirrors the enduring image of the Pacific region as being constituted by small, scattered, isolated islands-despite Epeli Hau'ofa's best efforts (Hau'ofa I993).

In my imagination these Europe-based scholars are surrounded by colleagues examining national and domestic issues, European Union developments, NATO politics, events in the transition states of the former Soviet Union, peacekeeping and reconstruction in the Balkans, the resurgence of right-wing political parties, or, as the occasion may call for, the legacy of philosophers like Karl Popper and the challenges of housing in the twentyfirst century. Some of their colleagues probably work on European aid policy in Africa or European trade with Asia and North America. It would make sense, since those are all pressing and relevant concerns in their national and regional contexts. But I wonder how Europeans studying the Pacific stay motivated? How they feel justified in studying distant islands, when so many things are happening at home and closer to home that demand their attention and command research funds? I wonder how their colleagues view their research and whether they accord it an equality of knowledge? 
I teach Pacific studies at a university located in the South Pacific, yet many times I feel I am surrounded by academics who believe the Pacific offers them little more than some color and entertainment, and that all they need to know to truly be in the world is in Europe/Africa/Latin America/Asia/Anglo-Austronesia (white Australia and New Zealand)that is, not in the island Pacific. If I have difficulty convincing my colleagues that Pacific studies has cachet on the global knowledge market, I wonder how members of the European Society for Oceanists fare. At least for me, when the university gets me down and I'm feeling homesick for Fiji, I have Wellington, a city with a vibrant contemporary Pacific arts scene-from hip-hop to theatre, filmmaking, comedy, visual arts, taro at the corner dairy, corned beef at the grocery store, and green coconuts at Woolworth's. I wonder how Europeans studying the Pacific stay inspired when their return visits for fieldwork and research in the Pacific are expensive and thus less frequent than they might prefer? Perhaps their fieldwork souvenirs keep their memories warm: a piece of tapa or a mat gifted to them and kept in a place of honor in their homes or offices; a collection of Te Vaka or Fenua CDs or recordings from the late Ad Linkels collection playing in their car stereos; biennial meetings with people who, if not exactly like-minded or kindred in spirit, at least know where they've been, know where they're "at," and could be interested in going somewhere with them ... if only conceptually.

There will always be hierarchies of knowledge, and whether the Pacific as an area of study barely registers on the scale of scholarly importance in Europe or America, or whether our collective word counts in refereed journals would approximate the worth of stone money/shell money/ feather money/fine mats/whales' teeth/greenstone or even a Iokg bag of rice in the most isolated village on the remotest motu . . . whether our work matters to the people we work on or work with, at the end of the day, whether we are studying/writing about/reflecting on the Pacific in the Pacific or far, far away, our work must matter to $u s$. What links all students of the Pacific, is the belief that our enquiries matter.

Once upon a time studying the Pacific was a noble career and widely recognized for its contributions to the advancement of human knowledge. Anthropology has had the most distinguished tradition, with Bronislaw Malinowski, Raymond Firth, and Margaret Mead breaking new ground for the discipline by way of the Pacific. Possibly just as significant in terms of both historiography and cultural theory, scholarship based on research in the Pacific has been acknowledged as having anticipated the "invention 
of tradition" debate in Europe and America by several years. James Clifford identifies this anticipation in Roy Wagner's The Invention of Culture (1975) and Roger M Keesing and Robert Tonkinson's Reinventing Traditional Culture: The Politics of Kastom in Island Melanesia (1982), whereas James West Turner locates it several years earlier in Peter France's I969 study of Fiji, The Charter of the Land (Clifford I997, I; Turner I997, 362). But somewhere along the way, the dialogue between studies of the Pacific and studies of humanity have broken down, so that those of us in Pacific studies who want to have dialogues across geo-cultural regions are faced with such an enormous level of ignorance that we are sometimes forced to draw analogies and make comparisons that we think will help attract critical attention to the Pacific.

I have recently been struck by the power of this compulsion and have noticed it in a number of European- and American-based grant proposals. One such proposal was premised on the notion that the way cultural diversity in the Pacific is lived out and negotiated could provide useful lessons for a Europe struggling with its own diversity-even going so far as to identify the ethnic conflicts in the former Yugoslavia as one of the motivating factors for the grant proposal to study the Pacific. A certain economic desperation along with a striking political and cultural naïveté underline this extraordinary stretching of historical and cultural comparison.

Less far-fetched, but just as problematic, are attempts to cast Pacific migrations as diasporic in order to cash in on the currency that diaspora studies presently has in sectors of academe. While I think it is fine and indeed necessary to examine the usefulness of applying analytical terms and concepts to the Pacific, uncritical and wholesale application of such descriptors is concerning. A substantial portion of my $\mathrm{PhD}$ dissertation attempted to establish a meaningful engagement between Pacific studies and cultural studies-including diaspora studies and postcolonial criticism (Teaiwa 200I). But rather than claiming the Pacific as diasporic or postcolonial, I tried to see where exactly Pacific phenomena and thought either converged with or diverged from these largely metropolitan-defined frameworks. More often than not, though, the Pacific is not brought to the table as an equal partner in any conversation about the nature of humanity or society. When lucky enough to be noticed, the Pacific is presented as a freakish survival of non-duplicatable utopias (a la Bougainville's Nouvelle Cythera, or "New Paradise" [Bougainville 1970]), or as late and ultimately unnecessary confirmations of already established Hobbesian truths (eg, 
Derek Freeman's Sāmoa [Freeman 1983]). Incorporating the Pacific into preexisting frames of knowing is not a new practice.

A term oft proffered to substitute for the Polynesian chiefly system is "feudalism." It is a specter sometimes invoked to squash Pacific Islanders' contemporary utopic visions, as in Douglas Borer's sharp critique of Hau'ofa's "Sea of Islands" thesis: "The people of Tonga, often smugly superior to other Pacific Islanders as the only race never completely colonized by Europeans, are openly proud of their own history of imperial glory predating European contact. In contrast ... Fijians have never even been truly unified in a national culture. This is reflected in the fact that the national government is of secondary importance to the decentralized power of the great council of chiefs. Like all European feudal lords, Fijian chiefs (and other Pacific island chiefs) are partially answerable only to a localized constituency: the village, the island, or the province" (Borer 1993, 86).

I am not aware of vigorous disputes over the application of the term "feudal" in precolonial Tongan or Fijian contexts, but Hawaiian scholar/ activist/poet Haunani-Kay Trask has taken issue with such equations in her essay, "From a Native Daughter" (I987). Historians in Hawai'i readily assumed a feudal relationship between ali'i and maka'āinana in ahapua'a (that is, between chiefs and commoners in a traditional land division extending from the uplands to the sea). But Trask insisted this must be interrogated and refuted in the light of an indigenous worldview and language in which land figured as equivalent to one's own body and family rather than as an inanimate object. Focusing on differences between the possessive pronouns "o' $u$ " (indicating deference and respect) and "a'u" (indicating mastery over), Trask demonstrated that both ali' $i$ and maka'āinana thus displayed deference and respect for the land, and though their relationship to each other was hierarchical, it was mutually dependent and necessarily respectful-existing in a separate epistemological or philosophical realm from European feudalism.

In a similar contribution, Hawaiian artist and Polynesian Voyaging Society cofounder Herb Kawainui Kane noted that the famous debate between Gananath Obeyesekere and Marshall Sahlins over the apotheosis of Captain Cook necessarily turned on foreigners' mistaken translation of the Hawaiian term "akua" into "god," with all its omniscient and allpowerful connotations in English (Obeyesekere 1992; Sahlins 1995). Kane claimed that akua in Hawaiian are frailer and certainly more malleable under human influence (Kane nd). So the question becomes not so much 
whether Hawaiians thought Cook was a god, but how Hawaiians conceived of what we are limited to calling gods in the English language.

I would not be satisfied with any philosophy that posited an absolute incommensurability of knowledge across cultures, so what worries me about some assertions of indigenous difference from "the West" is that they often do not account for changes in indigenous ways of knowing and being. Once, most Hawaiians and Pacific people in general saw land in the same way that they saw their own bodies or senior family members; once, most Hawaiians and Pacific people saw gods as fallible and accountable. But is that still the case? What triggers my curiosity here is how change in the Pacific gets collapsed with previously formed ways of knowing, how change in the Pacific gets incorporated into familiar models.

Almost as soon as Europeans arrived in the Pacific, those of them exploring in the Enlightenment and Romanticist traditions began lamenting the effects their presence and contact would have on the societies they encountered. Later travelers, like the primitivist successors to the Romanticists, would be dismayed by the "corruption" evident in everything from race mixing to substance abuse, proletarianization, and conversion, and so on. These changes have long come to be understood and accepted by most of us as indicators of a process of Europeanization, westernization, and modernization. Although a small body of literature prefers to argue Christian conversion as a process of indigenization (eg, Diaz I992), I am fairly confident in saying that the majority of social changes taking place in the Pacific are being analyzed as movement from being more Pacific to less Pacific, less European to more European, less modern to more modern, more exotic to more familiar. However, anthropologist James Carrier, in his study of village markets' articulations with the national economy in Papua New Guinea, warns of the danger of seeing westernization as the only or most important consequence of colonization (I992). A parallel argument has been made about consumerist Americanization not being the only or most important consequence of globalization, and the protests and mobilizations in Seattle, Genoa, Doha, and elsewhere do seem to indicate this.

But quite apart from the tendency to describe change in the Pacific as an inevitable march towards mimicking former and current colonizers, there is another trend in which change is described as having the properties or qualities of conditions in other developing world contexts. The drawing of such analogies and homologies is not a thoroughly worked 
out or well defined field in Pacific studies, although a few recent doctorates make substantial comparative analyses between Pacific examples and other settings (Ratuva 2000; Salesa 200I). My own introduction to the possibilities and problematic of applying terms across geopolitical regions came through writing by a Fijian scholar, the late Simione Durutalo.

In his I992 essay, "Anthropology and Authoritarianism in the Pacific Islands," Durutalo described political and economic developments in the Pacific by the United States and to a lesser extent France during the late stages of the cold war as a process of "Caribbeanization." Durutalo did not elaborate on the specific US or French activities in the Pacific that had inspired him to make this analogy in the title of one of the subsections of his essay. In the context of a world consciousness shaped by the cold war, however, Durutalo's invocation of the Caribbean was enough to conjure up images of CIA covert operations against and more blatant US military invasions on socialist leanings in the development of client states. While Durutalo documented an increase in levels of US aid and military assistance in the I980s to states in the Pacific outside its historical and colonial sphere of influence (such as Fiji, Tonga, and Papua New Guinea), I found the appropriateness of using the term Caribbeanization limited to particular features of international relations and the political economy of aid.

When in my PhD work I tried to follow on from Durutalo's work and draw closer comparisons between the Pacific and the Caribbean in the area of cultural politics, some glaring discrepancies emerged, most notably when it came to accounting for the enduring power of discourses of indigeneity in the Pacific-something superseded in the Caribbean by discourses of race and class. Of course, the function of an analogy is to posit not complete identification but rather agreement or similarity in a limited number of features. As Austrian scientist Konrad Lorenz noted in his 1973 Nobel lecture, "an analogy can be more or less detailed, and hence more or less informative" (Lorenz 1973). Durutalo's use of the term Caribbeanization was less detailed and less informative than it could have been. It is not even clear whether the situations in the Pacific and Caribbean of the cold war era are even homologous - that is, sharing similar structures. The effect of using the term "Caribbeanization" is largely rhetorical and somewhat alarmist, as other descriptions of political and economic crises in the region have also been.

Although no analyses of the May 1987 and subsequent coups and constitutional regressions in Fiji have used the terms "ethnic cleansing" or 
"apartheid" in a sustained manner, the specters of South Africa, the former Yugoslavia, and, in some recent commentaries, Sri Lanka, have been raised in numerous letters to the editors in daily papers, journalistic writing, and testimonials in international forums. In an article published on I7 February 200I in the New Zealand Herald, veteran journalist Gordon McLauchlan wrote:

What a shame the indigenous Fijians did not have the stature and generosity to overcome ... adversity and rescue their country once they had control of it. The task now seems far beyond them and the danger to New Zealand is we could have a Sri Lanka-style country as a near neighbour. . .

The current Fijian Government declared itself intellectually and spiritually bankrupt when spokesman Kotobalavu said of [another New Zealand journalist, Michael] Field that as "a palagi" (outsider) he had "no understanding and appreciation of Fijian and Pacific Island culture." ...

Perhaps the Fijian leadership should travel to Sheffield, England, for the next election there. It is about to become the largest British city with a majority of citizens of Asian origin.

Kotobalavu could watch these Asians casting their votes and reflect that most of them have been in Britain less time than Indo-Fijians have been in their native country.

Now, let's remind [Foreign Affairs Minister] Phil Goff of his brave words at the time of the coup in Fiji and treat him with the contempt he will deserve if he again allows any individual or group of people representing Fiji into this country, even if it is costly and inconvenient to us. I thought we'd sorted all that out when apartheid was still around. (McLauchlan 200I).

McLauchlan managed to compact several different comparisons in his short op-ed piece: Sri Lanka, England, and apartheid South Africa. He also referred to Kotobalavu's assertion of what Durutalo would call "Pacific exceptionalism"-but I will return to that later. Whereas once, both the threat and the promise of the Pacific was in becoming less Pacific and more Western, now it seems the promise of westernization has been forfeited and the Pacific is only in danger of becoming more and more "Third World." Because of the enormous differences in historical/cultural/economic backgrounds and most strikingly, in demographic and material scales of the conflicts in Fiji compared to South Africa, the Balkans, and Sri Lanka, the effects of drawing such comparisons is nothing if not hyperbolic.

But the comparison considered most hyperbolic, at least judging from 
the New Zealand media's reaction to it, would have been the one that caused a furor in New Zealand in 2000 when then Assistant Minister for Māori Affairs (now leader of the Māori Party established in 2004) Tariana Turia used the term "holocaust" to describe the effects of colonization on Māori. Turia was subsequently censured by her prime minister, Helen Clark, and even as Clark's government promoted an ambitious social and economic policy of "closing the gaps" between Māori and Pacific communities and European or Pākehā New Zealanders, an all-out ban was placed on members of parliament using the " $h$ " word in reference to the Māori experience (NZH 200ob, 2000c).

There is a very particular sensitivity that arises when attempting to claim for other groups the same kind of horror as the Holocaust for Jews under Nazism. However, American historian Howard Zinn, himself of Jewish descent, believes that comparisons across historical periods and geo-political regions are an ethical imperative. In a 1999 essay, Zinn described the outrage engendered when in the I980s he was asked by a Jewish group to speak on the Holocaust and he chose instead to speak to them of the US government-sponsored death squads responsible for the deaths of hundreds of thousands of peasants in Guatemala and El Salvador. Zinn explained: "My point was that the memory of the Jewish holocaust should not be encircled by barbed wire, morally ghettoized, kept isolated from other genocides in history. It seemed to me that to remember what happened to Jews served no important purpose unless it aroused indignation, anger, action against all atrocities, anywhere in the world" (Zinn I999).

I would like to spend a little more time on Zinn's explication of the path to humanism that comparative analysis can pave. Zinn described as "shameful" the lobbying by a Jewish organization against the recognition in the US Holocaust Museum of the I9I 5 Armenian holocaust and the killing of millions of non-Jews by Hitler: "When Jews turn inward to concentrate on their own history and look away from the ordeal of others, they are, with terrible irony, doing exactly what the rest of the world did in allowing the genocide to happen" (Zinn I999). He went on to say: "To build a wall around the uniqueness of the Jewish Holocaust is to abandon the idea that humankind is all one, that we are all, of whatever color, nationality, religion, deserving of equal rights to life, liberty and the pursuit of happiness. What happened to the Jews under Hitler is unique in its details but shares universal characteristics with many other events in human history: the Atlantic slave trade, the genocide against Native Amer- 
icans, the injuries and deaths of millions of working people, victims of the capitalist ethos that put profit before human life" (Zinn 1999).

I daresay that if Howard Zinn knew about the experiences of certain Māori tribes that he might have defended Tariana Turia's right to use the " $h$ " word. But what would need to be clarified is the spirit in which Māori might use the holocaust as a rhetorical device-would it be simply to further legitimize their claims under the existing compensation and awards process of the Treaty of Waitangi Tribunal? Or would it be to link their struggle to recover from the past with an ongoing struggle to prevent any more atrocities in the present and future? For Helen Clark, the question was by no means settled. Further paranoia about reference to the holocaust and reluctance to offend Jewish communities in New Zealand were influenced by a national scandal several months prior to Turia's comment, when it was revealed that a New Zealand university had awarded an $\mathrm{A}+$ grade to an MA thesis that had argued that the Jewish holocaust never took place (NZH 200I, 2000a). Needless to say, cross-cultural and cross-historical comparisons can sometimes be heavily loaded and deployed in highly charged situations. Turia was a victim of her own narrow reading of history and articulation of cultural politics and party protocols; Clark was a victim of the same. Reflecting on this conflict over the appropriateness of analogy in the realm of victimhood has provided me with valuable material for reflection on the ethical dimensions of historical and cross-cultural comparison.

But the real catalyst for my topic came about because of my apprehension regarding the strength of a current within some foreign affairs and international relations circles in New Zealand and Australia that is ascribing to the recent turmoil in the Pacific region the signature of "Africanization" (Shearer 2000). In an article in the Australian Journal of International Affairs in 2000 Ben Reilly asserted:

In the past year, the perception of the South Pacific has changed from an "oasis of democracy" to an "arc of instability," with the violent overthrow of the elected government in Fiji, an ethnic civil war . . . in the Solomon Islands, military insubordination in Vanuatu, ongoing political instability in PNG, the killing of a cabinet minister in Samoa.... In addition, the region has become mired in sub-standard economic performance.... on many indicators of development, the South Pacific region is on a par with sub-Saharan Africa in terms of its per capita GDP, literacy and schooling rates, public health statistics and, ominously, in its increasing lack of economic opportunity for young job seekers. (Reilly 2000, 262) 
It still surprises me how short a sense of history foreign affairs and international relations analysts have. Very few who actually lived through or observed the decade of the r980s in the Pacific would describe the French use of military violence against Kanaks in New Caledonia, the assassination of a Belauan premier by a pro-American and pro-nuclear conspiracy, the genocidal policies of Indonesia in East Timor and West Papua, as well as the military coups in Fiji as exemplars of an "oasis of democracy" prior to the year 2000. Nevertheless, the United Nations Development Program's Pacific Human Development Report, released in I999, confirmed Reilly's claim that certain indicators in the region are on par with African states; for example, Papua New Guinea's human development index ranking (O.3I4) is similar to that of Djibouti and Chad-two of Africa's poorest countries. While there is a degree of indignation that surfaces from Pacific Island leaders at being compared to Africa, Reilly's article does deserve to be examined more closely rather than dismissed, and others have begun to do this (Fraenkel 2002; Chappell 2005). While I am concerned about the veracity of some of Reilly's claims, I am most interested in his thesis as one of the most ambitious recent attempts to fully develop an analogy between the Pacific and another Third World frame of reference.

Reilly identified four features of this process of Africanization:

- the growing tensions in the relationship between civil regimes and military forces;

- the intermixture between ethnic identity and the competition for control of natural resources as factors driving conflicts;

- the weakness of basic institutions of governance such as prime ministers, parliaments and, especially, political parties; and

- the increasing centrality of the state as a means of gaining wealth and of accessing and exploiting resources.

He proposed, "Taken together, these factors indicate a growing weakness of democracy and an increasing likelihood of further troubles in the region in the future. In particular, they indicate that some of the problems that have plagued states in sub-Saharan Africa may well be emerging in the South Pacific as well" (Reilly 2000, 263).

Reilly's predictions echo earlier doomsaying out of the Australian National University in a report titled Pacific 20 Io (Cole 1993), for which Greg Fry has provided an exemplary critique (Fry 2000). One cannot help 
but feel from the "Pacific 2010" and Africanization schools of thought that a certain pleasure is being derived from stripping the Pacific of its paradisiacal facade. But Reilly's article starts to get into trouble and falls into the avoidable trap of hyperbole when it attempts to assert more precise similarities between the Pacific and Africa:

In Africa, a process that began in the I970s with the departure of white farmers from countries like Kenya, Malawi and Mozambique as part of the liberation struggle, turned into a Fiji-like crusade against the community from the Indian subcontinent in Uganda when Idi Amin forced thousands of ethnic Indians, who played a vital role in the country's economy, to leave the country. We are now seeing the end-game of this process of coerced removal being played out by Robert Mugabe in Zimbabwe, as this country's remaining white farmers are being slowly forced out of the country. This has frightening parallels with the likely consequences of George Speight's seizing of power in Fiji, which has left the country's Indo-Fijian population ... with nowhere to go but out. Amin's actions badly damaged the fragile Ugandan economy; Mugabe's actions attacked the economic lifeblood of Zimbabwe; and Speight's actions will just as surely wreak havoc upon the economy of Fiji. (Reilly 2000, 264)

Reilly's first mistake was inverting his ethno-chronology by describing Idi Amin's expulsion of Indians as a "Fiji-like crusade." No such official expulsions of Indians have ever taken place in Fiji and certainly none that would predate Idi Amin's. Reilly's attempt to make the position of white farmers in Southern Africa equivalent to that of Indo-Fijians is also erroneous if one takes into account the historical basis of their settlement and respective land tenure. White farmers in Southern Africa inherited land and property ostensibly stolen from Africans by their ancestors; IndoFijians could claim no such inheritance, or stigma. Reilly extended his exaggeration to paralleling Robert Mugabe's Zimbabwe with George Speight's (much more tenuous hold over) Fiji; his prediction that Speight left Indo-Fijians with "nowhere to go but out" displays a poor sense of the social, economic, and emotional conditions that in reality prevent most Indo-Fijians from leaving the country.

Whereas it might seem easy enough to brush off this Africanization model as out-and-out obfuscation by a handful of academics and bureaucrats in Australia and New Zealand, I was exposed to the potential spread of this metaphor when a part-Fijian stage director friend of mine in Wellington was contracted to produce Nigerian Nobel Laureate and playwright Wole Soyinka's satirical play, King Baabu. My friend, who has 
never lived in Fiji and has only visited there a couple of times, was given explicit instructions by her employers to produce the play as a commentary on militarization and corruption in the Pacific-in other words, as a commentary on the Africanization of the Pacific, with specific reference to Fiji. The play was to be performed before Wole Soyinka himself and he would be invited to comment further on the production with a small panel of speakers. My friend was both honored and dismayed by her task and in the end "pacificized" the play by making King Baabu and his wife ambitious Samoans surrounded by a host of Māori-ized and otherwise generic characters. The results were hilarious, but she had not made any specific references to Fiji, so for this reason she arranged for me to be on the panel after the play so that I might cast some light on the resonances King Baabu had for Fiji.

Combined with my nervousness at sharing the floor with the Nobel Laureate, I had a great deal of ambivalence about speaking to the subject, and was wary of being positioned to pathologize both Fiji and Africa in the "Africanization of the Pacific" vein. When the inevitable question came from the panel chair about parallels between Soyinka's play and recent events in Fiji, I composed my response with a series of more questions: Why are corruption, militarization, and conflict the signifiers of Africanization? How did Africa get landed with the blame for inventing corruption, militarization, and conflict? Why don't people refer to the popularization of African music through bands like Oyabaa, Johnny Clegg and Savuka, and Lucky Dube, or poetry and village theatre, as the "Africanization of the Pacific"?

The ultimate problem with the comparisons and analogies I have discussed so far is their reduction of very complex histories and realities to simple characteristics and features, combined with their insistence on analyzing politics and history separately from culture. Is the solution to ignore similarities across cultures and geopolitical regions and resort to the kind of righteous self-absorption that Howard Zinn decried? Simione Durutalo, whose work-except for the lapse with the concept of Caribbeanization-continues to provide for me the most politically incisive, ethically grounded, and consistently humanistic analyses to emerge from the Pacific, elegantly captures the character of exceptionalism and what we might also call the reification of the indigenous:

The concept of the Pacific Way (and its subsidiary the Melanesian Way) represents the most articulate expression of this sense of Pacific exceptionalism, 
which claims that the Pacific Islands are unique societies that have to be studied on their own terms and will therefore need a totally new methodology to understand them. The ideologues of the Pacific assert that although social classes may exist in other parts of the world, they are nonexistent in the Pacific Islands and any discussion of surplus extraction and exploitation in such societies, then and now, is but a futile academic exercise [Tupouniua and others 1975; Vusoniwailala 1978; Narokobi 1980, x, I7I]. This emphasis on traditionalism and exceptionalism can be traced to the early twentieth-century works of ... Malinowski, Firth, and Mead, who have held the greatest responsibility for perpetuating a static and functionalist view of Pacific Island societies that does not fit contemporary realities. This was done through their elimination of innovation in their descriptions of island economic and sociopolitical systems. (Durutalo I992, 207-208)

In circling back and linking the ideologues of Pacific exceptionalism with the anthropology of Malinowski, Firth, and Mead, Durutalo raises crucial questions about the ease with which valid ethnographic data can be refashioned as ahistorical truth. Could it be that the very scholars who put the Pacific on an equal footing with other geo-cultural regions in the great global/metropolitan (European and American) seminars on the humanities and social sciences were also inadvertently responsible for the Pacific's demotion and relegation to the peripheries of humanistic discourse? Perhaps it is simply that Malinowski, Firth, and Mead have too few heirs worthy to speak of in our region; that certainly seemed to be a source of anxiety for some participant observers in the field of history (see Routledge 1985; Howe 1977).

I have no solutions to the problem of the Pacific's marginalization in a global arena. What I do know is that we must not stop our investigations, explorations, ruminations in Pacific studies simply because the world marketplace of knowledge does not value this region as we do. Neither must we give in to the tempting rhetoric of Pacific exceptionalism-our greatest crime would be to ghettoize ourselves. After all is said and done, and I grit my teeth as I admit this: it is better to have attempted an inappropriate analogy and a false homology than to have ignored all possible points of comparison. Finally, it is not our intellectual agility in making comparisons that is to be admired, but our ability to discern the useful from the misleading comparisons that will save us from irrelevance and obscurity.

As Durutalo prescribed for island intellectuals, we need "to take cognizance of separable cases, moving through and beyond them and transforming them. . . . to do otherwise is to risk being ahistorical by falling 
into the trap of examining ideas and institutions in isolation" (I992, 2092ro). Whether we live and study the Pacific in the islands, or study the Pacific from continental distances, Durutalo's words, published almost fifteen years ago and just over a year before his untimely death, are as relevant and urgent today as they were then.

Thanks to Vilsoni Hereniko and Jan Rensel for their desire to give this paper a home in print; and to two anonymous reviewers as well as my former colleague Paul D'Arcy for advice on revising the paper for publication. My gratitude to Sean Mallon for encouraging and protecting the conditions under which I can think and write at home. This paper is dedicated to the memory of Simione Durutalo (1956-I994).

\section{References}

Borer, Douglas

I993 Truth or Dare. In A New Oceania: Rediscovering Our Sea of Islands, edited by Eric Waddell, Vijay Naidu, and Epeli Hau'ofa, 84-87. Suva: School of Social and Economic Development, University of the South Pacific, in association with Beake House.

Bougainville, Louis Antoine de

1970 News from New Cythera: A Report of Bougainville's Voyage, I766I769. Edited by L Davis Hammond. Facsimile edition. Minneapolis: University of Minnesota Press.

Carrier, James

1992 Approaches to Articulation. In History and Tradition in Melanesian Anthropology, II6-I43. Berkeley: University of California Press.

Chappell, David

2005 "Africanization" in the Pacific: Blaming Others for Disorder in the Periphery? Comparative Studies in Society and History 47 (2): 286317.

Clifford, James

I997 The Invention of Tradition Reconsidered. Paper presented at the "Questions of Tradition" conference, Rutgers University, I3-I6 November.

Cole, Rodney V, editor

1993 Pacific 2010: Challenging the Future. Canberra: National Centre for Development Studies, Australian National University.

Diaz, Vicente

1992 Repositioning the Missionary: The Beatification of Father Diego Luis 
de Sanvitores and Chamorro Cultural History. PhD dissertation, University of California, Santa Cruz.

Durutalo, Simione

1992 Anthropology and Authoritarianism in the Pacific Islands. In Confronting the Margaret Mead Legacy: Scholarship, Empire, and the South Pacific, edited by Lenora Foerstel and Angela Gilliam, 205-232. Philadelphia: Temple University Press.

Fraenkel, Jonathan

2002 The Coming Anarchy in Oceania? A Critique of the "Africanization of the South Pacific" Thesis. Paper presented at the Pacific History Association Annual Conference, Apia, Sāmoa, 9-13 December.

France, Peter

I969 The Charter of the Land. Melbourne: Oxford University Press.

Freeman, Derek

I983 Margaret Mead and Samoa: The Making and Unmaking of an Anthropological Myth. Cambridge, MA: Harvard University Press.

Fry, Greg

2000 Framing the Islands: Knowledge and Power in Changing Australian Images of the "South Pacific." In Voyaging through the Contemporary Pacific, edited by David Hanlon and Geoffrey M White, 25-63. Lanham, MD: Rowman and Littlefield. First published in The Contemporary Pacific 9:305-344 (1997).

Hau'ofa, Epeli

I993 Our Sea of Islands. In A New Oceania: Rediscovering Our Sea of Islands, edited by Eric Waddell, Vijay Naidu, and Epeli Hau'ofa, 2-I6. Suva: School of Social and Economic Development, University of the South Pacific, in association with Beake House. Reprinted in The Contemporary Pacific 6:I47-I6I (I994).

Howe, K R

I977 The Fate of the "Savage" in Pacific Historiography. New Zealand Journal of History II:I37-I 54.

Kane, Herb Kawainui

nd Where Marshall Sahlins Goes Wrong: How One Native Hawaiian Thinks: About Some Ethnologists, for Example. Manuscript, in author's possession.

Keesing, Roger M, and Robert Tonkinson

I982 Reinventing Traditional Culture: The Politics of Kastom in Island Melanesia. Mankind I3:4. Sydney: Anthropological Society of New South Wales.

Lorenz, Konrad Z

I973 Analogy as a Source of Knowledge. Nobel Lecture, I2 December. <http://www.nobel.se/medicine/laureates/r973/lorenz-lecture.pdf> 
McLauchlan, Gordon

200I I'm Staying Away from Fiji Until . . . New Zealand Herald, I 7 February. <http://www.nzherald.co.nz/index.cfm?ObjectID $=\mathrm{I} 72636>$

Narokobi, Bernard

I980 The Melanesian Way. Edited by Henry Olela. Boroko: Institute of Papua New Guinea Studies.

NZH, New Zealand Herald

2000 A-plus Equals Anger for Jewish Groups. 22 December. < http://www .nzherald.co.nz/index.cfm? ObjectID $=\mathrm{I} 66 \mathrm{I} 26 \mathrm{>}$

200ob Holocaust Apology Puts Minister in Hot Water. 6 September. <http:// www.nzherald.co.nz/index.cfm?ObjectID $=$ I $50333>$

2000c What Tariana Turia Said-in Full. 3I August. < http://www.nzherald .co.nz/index.cfm? ObjectID $=\mathrm{I} 49643>$

200I Holocaust Denial Viewed as World Class Blunder. 20 January. <http:// www.nzherald.co.nz/index.cfm? ObjectID = I 69 I $16>$

Obeyesekere, Gananath

I992 The Apotheosis of Captain Cook: European Mythmaking in the Pacific. Princeton, NJ: Princeton University Press.

Ratuva, Sitiveni

2000 Ethnic Politics, Communalism and Affirmative Action in Fiji: A Critical and Comparative Study. DPhil Thesis, University of Sussex.

Reilly, Ben

2000 The Africanisation of the South Pacific. Australian Journal of International Affairs 54 (3): 26I-268.

Routledge, David

I985 Pacific History as Seen from the Pacific Islands. Pacific Studies 8 (2): $8 \mathrm{I}-99$.

Salesa, Damon

200I Race Mixing: A Victorian Problem in Britain and New Zealand, I830sI 870. DPhil Thesis, Oxford University.

Sahlins, Marshall

I995 How "Natives" Think: About Captain Cook, For Example. Chicago: University of Chicago Press.

Shearer, David

2000 Beyond Bikinis and Balaclavas. The World Today 56 (I I): 22-24.

Teaiwa, Teresia K

200I Militarism, Tourism and the Native: Articulations in Oceania. PhD Thesis, University of California, Santa Cruz.

Trask, Haunani-Kay

I987 From a Native Daughter. In The American Indian and the Problem of History, edited by Calvin Martin, I7I-I79. New York: Oxford University Press. 
Tupouniua, Sione, Ron Crocombe, and Claire Slatter, editors

I975 The Pacific Way: Social Issues in National Development. Suva: South Pacific Social Sciences Association.

Turner, James West

I997 Continuity and Constraint: Reconstructing the Concept of Tradition from a Pacific Perspective. The Contemporary Pacific 9:345-38I.

Wagner, Roy

I975 The Invention of Culture. Englewood Cliffs, NJ: Prentice Hall. UNDP, United Nations Development Program

1999 Pacific Human Development Report. Suva: UNDP.

Vusoniwailala, Lasarusa

I978 Toward a Pacific Island Theory of Communication and Change. MA thesis, Communication, University of Hawaíi at Mānoa.

Zinn, Howard

I999 A Larger Consciousness. Io October. < http://www.zmag.org/ sustainers/content/I999-Io/Iozinn.htm> 